\title{
PENGARUH KOMITMEN BERINOVASI TERHADAP BUDAYAMUTU DOSEN DI UNIVERSITAS MUHAMMADIYAH LUWUK
}

\author{
Farid Haluti \\ Universitas Muhammadiyah Luwuk \\ email: fhaluti@yahoo.co.id
}

\begin{abstract}
Abstrak
Keberadaan dosen menentukan mutu pendidikan dan lulusan suatu perguruan tinggi. Guna menjalankan pendidikan perguruan tinggi diperlukan dosen yang memiliki kualifikasi akademik, kompetensi dan sertifikasi agar terciptanya budaya mutu dosen itu sendiri. Budaya mutu dosen merupakan sistem makna bersama terhadap nilai-nilai primer yang dianut bersama dan dihargai organisasi. Keberhasilan perguruan tinggi dalam penciptaan budaya mutu ditentukan oleh komitmen berinovasi dosen berdasarkan bidang keahliannya sehingga melahirkan kompetensi profesional. Komitmen berinovasi menunjukkan suatu daya dari dosen untuk mengidentifikasikan keterlibatannya sebagai bagian sistem perkuliahan di perguruan tinggi. Penelitian ini bertujuan mengetahui komitmen berinovasi berpengaruh langsung terhadap budaya mutu pada dosen di Universitas Muhammadiyah Luwuk. Menggunakan metode survey kausal dengan model analisis jalur untuk menguji pengaruh langsung komitmen berinovasi terhadap budaya mutu dosen di Univeritas Muhammadiyah Luwuk. Sampel penelitian ini diambil secara proporsional secara random sampling berjumlah 67 responden dari 111 orang. Data hasil pengukuran variabel komitmen berinovasi dan budaya mutu dosen dikumpulkan melalui angket, observasi dan wawancara serta dianalisis secara deskriptif dan inferensial. Secara deskriptif budaya mutu dosen mencapai rata-rata 115 dan standar deviasi sebesar 11,84, dengan 24 orang (39\%) memperoleh skor dibawah rata-rata, sebanyak 12 orang (18\%) skor berada pada rata-rata dan sebanyak 31 orang $(43 \%)$ memperoleh skor di atas rata-rata. Hasil variabel komitmen berinovasi diperoleh rata-rata sebesar 101,76 dan standar deviasi sebesar 11,60, dengan 30 orang (45\%) memperoleh skor dibawah rata-rata, sebanyak 15 orang (22\%) memiliki skor pada ratarata dan sebanyak 22 orang (33\%) mendapatkan skor di atas rata-rata. Hasil uji menunjukkan terdapat pengaruh langsung positif komitmen berinovasi terhadap budaya mutu dosen di Universitas Muhammadiyah Luwuk. Terciptanya budaya mutu perguruan tinggi dipengaruhi adanya komitmen berinovasi dosen berdasarkan bidang keahliannya.
\end{abstract}

Kata Kunci: Komitmen Berinovasi, Budaya Mutu Dosen dan Pengaruh Komitmen Berinovasi terhadap Budaya Mutu Dosen.

\section{A. PENDAHULUAN}

Dosen memegang peranan yang strategis bagi kemajuan suatu perguruan tinggi. Keberadaan dosen menentukan mutu pendidikan dan lulusan yang dilahirkan perguruan tinggi. Apabila dosen berkualitas tinggi, tentu akan mendorong terciptanya kualitas perguruan tinggi, demikian pula sebaliknya. Guna menjalankan program pendidikan perguruan tinggi yang baik diperlukan para dosen yang bermutu tinggi. Pemenuhan mutu dosen dan kualitas perguruan tinggi sesuai yang diharapkan UU No. 14 Tahun 2015 tentang Guru dan dosen yang mensyaratkan bahwa seorang dosen harus memiliki kualifikasi akademik, kompetensi dan sertifikasi. Kualifikasi yang dimiliki dosen dalam aktivitas perkuliahan diharapkan mendorong terciptanya budaya mutu dosen itu sendiri.

Budaya mutu dosen pada perguruan tinggi adalah suatu keniscayaan dalam menjalankan aktivitas dan selalu mengalami perubahan. Menurut Robbins (2001: 525), budaya mutu merupakan sistem makna bersama terhadap nilai-nilai primer yang dianut bersama dan dihargai organisasi, berfungsi menciptakan pembedaan antara satu organisasi dengan organisasi lainnya. Dosen yang merasa bangga menjadi bagian organisasi, menyenangi dan mempercayai satu sama lain, menyumbangkan tenaga dan pikiran dalam semangat kolektif untuk bersama 
memajukan budaya mutu pada perguruan tinggi secara berkesinambungan.

$$
\text { Stoner et.al. }
$$

mendefinisikan budaya mutu sebagai suatu cognitive framework yang meliputi sikap, nilai-nilai, norma perilaku dan harapanharapan yang disumbangkan oleh anggota organisasi. Davis (2004:198) menyatakan bahwa budaya mutu merupakan pola keyakinan dan nilai-nilai organisasi yang dipahami, dijiwai dan dipraktekkan oleh organisasi sehingga pola tersebut memberikan arti tersendiri dan menjadi dasar aturan berperilaku dalam organisasi. Proses pengembangan budaya mutu dimulai dari kesepakatan atas nilai-nilai yang diyakini, kondisi lingkungan kerja sebagai pilihan acuan untuk diinternalisasikan dalam setiap dosen dan diterapkan melalui aktivitas tugas sebagai dinamika perguruan tinggi.

Keberhasilan perguruan tinggi dalam penciptaan budaya mutu ditentukan oleh komitmen berinovasi dosen berdasarkan bidang keahliannya sehingga melahirkan kompetensi profesional. Komitmen berinovasi harus dimiliki setiap profesi dosen sebagai modal dasar untuk menghasilkan karya-karya yang berkualitas dalam melaksanakan tugas perkuliahan. Komitmen berinovasi menunjukkan suatu daya dosen untuk mengidentifikasikan keterlibatannya sebagai bagian sistem perguruan tinggi. Menurut Bernadib (2002: 116), komitmen adalah penerimaan yang kuat dari individu terhadap tujuan dan nilai-nilai dimana individu tersebut bekerja, berusaha, berkarya dan memiliki hasrat yang kuat untuk tetap bertahan. Komitmen berinovasi dapat menimbulkan suatu rasa ikut memiliki (sense ofbelonging) terhadap organisasi tempat ia bekerja. Adanya rasa ikut memiliki, seorang dosen merasa jiwanya terikat dengan nilai-nilai organisasi perguruan tunggi, sehingga diharapkan memiliki budaya mutu dalam menjalani rutinitas yang berkaitan dengan pekerjaaannya.

Berdasarkan uraian diatas dapat dikatakan bahwa keberadaan dosen di perguruan tinggi, khususnya di Universitas Muhammadiyah Luwuk merupakan faktor yang menentukan dari sekian banyak faktor pendidikan tinggi yang ada. Olehnya itu, seorang dosen dalam melaksanakan tugas profesinya diharapkan memiliki komitmen berinovasi, sehingga dosen Universitas Muhammadiyah Luwuk menjadi profesional dan memiliki kompetensi yang memadai. Hasil pengamatan peneliti pada dosen di Univeristas Muhammadiyah Luwuk menunjukkan bahwa sebagian diantara dosen bersikap apatis terhadap pengembangan budaya mutu dan rasa kepemilikan persaingan yang masih rendah sehingga budaya mutu belum nampak. Rendahnya komitmen berinovasi dosen diketahui melalui tidak kreatifnya dosen dalam melaksanakan perkuliahan, menggunakan cara-cara mengajar yang bersifat tradisional

Hasil observasi terhadap masalah yang diduga mempengaruhi budaya mutu dosen diantaranya adalah kurangnya: disiplin dalam mengerjakan tugas, tanggungjawab dan ketekunan dalam melaksanakan tugas, semangat dan kepedulian dalam bekerja, motivasi dalam melaksanakan tugas, kurangnya keakraban antar dosen, dosen dengan pimpinan fakultas dan Universitas, kurangnya kerjasama dosen dengan pegawai administrasi. Kondisi ini menggambarkan budaya mutu dan komitmen berinovasi dosen perlu dikaji melalui penelitian dengan judul, "Pengaruh Komitmen Berinovasi terhadap Budaya Mutu Dosen di Universitas Muhammadiyah Luwuk". Masalah yang berusaha dijawab dalam penelitian ini adalah apakah komitmen berinovasi berpengaruh langsung terhadap budaya mutu pada dosen di Universitas Muhammadiyah Luwuk? Penelitian yang bertujuan mengetahui komitmen berinovasi berpengaruh langsung terhadap budaya mutu pada dosen di Universitas Muhammadiyah Luwuk, diharapkan: (1) memberikan informasi bagi pengelolaan manajemen SDM dan segala kebijakan yang berkaitan langsung dengan aspek-aspek SDM secara lebih baik; (2) memberikan informasi sehubungan dengan kondisi nyata univeristas Muhammadiyah Luwuk baik dari sisi dosen maupun karyawan terhadap respon berbagai aturan atau kebijakan yang telah ditetapkan; dan (3) memberikan energi baru untuk melakukan perubahan dalam melaksanakan tugas sebagai dosen profesional. 


\section{B. KAJIAN TEORITIS \\ Budaya Mutu}

Menurut Robbins (2001: 525) bahwa budaya mutu merupakan sistem makna bersama terhadap nilai-nilai primer yang dianut bersama dan dihargai organisasi, berfungsi menciptakan pembedaan yang jelas antara satu organisasi dengan organisasi lainnya, menciptakan rasa identitas bagi anggota organisasi, mempermudah timbulnya komitmen kolektif terhadap organisasi, meningkatkan kemantapan sistem sosial, serta menciptakan mekanisme pembuat makna dan kendali yang memandu pembentukan sikap dan perilaku anggota organisasi. Gibson et.al. (2006:77) merumuskan bahwa kultur organisasi mengandung bauran nilai-nilai, kepercayaan, asumsi, persepsi, norma, kekhasan dan pola perilaku.

Meskipun konsep budaya mutu memunculkan perspektif yang beragam, namun budaya mutu berkaitan dengan sistem makna bersama yang diyakini oleh anggota organisasi. Setiap organisasi perlu ada upaya untuk menghasilkan budaya mutu yang kondusif bagi perbaikan berkelanjutan sehingga setiap anggota organisasi dapat berpartisipasi. Selain itu perlu ada jaminan kualitas yang diintegrasikan ke dalam semua proses dan fungsi organisasi. Semua itu memerlukan perubahan perilaku orang-orang, sikap mental dan praktek pekerjaan dalam berbagai cara. Mengubah perilaku dan sikap mental orang adalah salah satu tugas manajemen yang paling sulit, memerlukan kekuatan besar dan keterampilan persuasif dan memotivasi.

Budaya mutu merupakan suatu standar yang menjadi dasar untuk mengukur capaian hasil kerja. Budaya mutu juga dapat dijadikan sebagai alat pembeda dengan produk/jasa sejenis lainnya, yang dihasilkan oleh lembaga lain sebagai pesaing (competitors). Para pelanggan secara individual dapat memberikan penilaian dan makna yang berbeda terhadap mutu suatu produk. Hal ini dipengaruhi oleh persepsi masing-masing berdasarkan tingkat kepuasan mereka atas produk tersebut, dan juga bergantung pada konteksnya. Oleh karena itu, organisasi atau lembaga pendidikan dituntut untuk menetapkan perencanaan mutu, termasuk membuat standar mutu, mulai mutu input hingga mutu hasil yang akan menjadi pedoman proses implementasi, sampai ke pengawasan dan perbaikan mutu.

\section{Dimensi-Dimensi Budaya Mutu}

Pengembangan budaya mutu lembaga pendidikan merupakan tugas dan tanggung jawab pemimpin pendidikan. Pengembangan budaya mutu lembaga pendidikan mempersyaratkan adanya partisipasi seluruh personilnya dan stakeholder, termasuk orang tua peserta didik. Oleh karena itu, secara manajerial pengembangan budaya mutu lembaga pendidikan menjadi tanggung jawab kepala lembaga pendidikan, sedangkan secara operasional sehari-hari menjadi tugas seluruh personil lembaga pendidikan dan stakeholder terkait. Hal ini sesuai pendapat Luthans (Lako, 2004: 33) bahwa terdapat 6 (enam) dimensi budaya mutu, yaitu: (1) peraturan perilaku yang diamati, (2) norma, (3) nilai yang dominan, (4) filosofi kebijakan, (5) aturan yang berlaku, dan (6) keyakinan.

Suasana dan hubungan formal dan informal dibangun dalam rangka memperlancar dan memperkokoh komitmen dari semua warga satuan pendidikan, dan sangat memperhatikan hubungan tersebut dengan wali peserta didik. Suasana kondusif yang dibangun tersebut melalui: (a) adanya komunikasi pimpinan dengan pendidik/warga satuan pendidikan dan melalui koordinasi yang kontinu, (b) pemberian pengakuan bagi yang berprestasi oleh satuan pendidikan, (c) tidak diatur hubungan yang kaku tetapi saling menghormati dan akrab, dan (d) suasana yang dibangun oleh satuan pendidikan adalah suasana maju, kreatif, inovatif, berbuat yang terbaik, tuntutan kerja keras, koordinasi yang baik, mempunyai struktur kepegawaian yang jelas, hubungan antar individu dan antara bawahan pimpinan baik, serta perhatian secara individu peserta didik oleh pendidik; (e) meskipun demikian tetap diterapkan mekanisme yang jelas bagi warga satuan pendidikan yang melakukan pelanggaran satuan pendidikan.

Berdasarkan beberapa pendapat yang telah diuraikan, budaya mutu dalam penelitin ini adalah suatu perilaku yang dikembangkan oleh suatu kelompok untuk mengarahkan, mendasari identitas anggota organisasi, serta menciptakan perbedaan yang jelas antara satu organisasi dengan organisasi lainnya dengan indikator yaitu percaya diri, berinovasi dalam 
melaksanakan tugas, memiliki gagasan dalam memecahkan masalah, berani melakukan perubahan, bekerja sesuai standar dan aturan yang ditetapkan.

\section{Komitmen Berinovasi}

Komitmen merupakan kemauan untuk menyelaraskan perilaku pribadi dengan kebutuhan, prioritas dan sasaran kelompok, mencakup cara-cara mengembangkan tujuan atau memenuhi kebutuhan kelompok, mendahulukan misi kelompok dari kepentingan pribadi. Menurut Jackson (2001: 119), komitmen adalah tingkat sejauhmana seseorang yakin dan menerima tujuan organisasi, serta berkeinginan untuk tinggal bersama atau meninggalkan organisasi pada akhirnya tercermin dalam ketidakhadiran dalam berbagai kegiatan. Griffin (Wang, 2009:2) menjelaskan bahwa komitmen adalah sikap yang mencerminkan sejauhmana seseorang mengenal dan terikat pada aturan dan norma yang telah ditetapkan. Menurut Luthan (2005: 211) bahwa komitmen dicirikan sebagai: (1) keinginan kuat untuk tetap sebagai melaksanakan tugas tertentu; (2) keinginan untuk berusaha keras sesuai keinginan organisasi; dan (3) keyakinan tertentu dan penerimaan nilai dan tujuan organisasi. Pendapat ini menunjukkan bahwa komitmen merupakan suatu sikap yang merefleksikan loyalitas berkelanjutan dalam mengekspresikan perhatian terhadap tugas guna mencapai keberhasilan atau kemajuan. Allen dan Meyer (2001: 126) mengatakan ada tiga dimensi komitmen, yaitu: (1) komitmen efektif adalah keterikatan emosional dan keterlibatan dalam pelaksanaan pekerjaan, (2) komitmen berkelanjutan adalah komitmen berdasarkan kerugian yang berhubungan dengan keluarnya seseorang dari kegiatan tertentu, (3) Komitmen normatif adalah perasaan wajib untuk tetap melaksanakan tugas karena memang tindakan tersebut merupakan hal benar yang harus dilakukan.

Berdasarkan ketiga dimensi tersebut, Dessler (Wang, 2009:2) memberikan pedoman khusus untuk meningkatkan komitmen dalam melaksanakan tugas yaitu (1) Berkomitmen pada nilai manusia yaitu membuat aturan tertulis, memperkerjakan manejer yang baik dan tepat, mempertahankan komunikasi, (2) memperjelas dan mengkomukasikan misi tugas (3) Memperjelas misi dan ideologi; berkharisma; menggunakan praktik perekrutan berdasarkan nilai; menekankan orientasi berdasarkan nilai dan pelatihan; membentuk tradisi, (4) Menjamin keadilan yaitu memiliki prosedur penyampaian keluhan yang komprehensif; menyediakan komunikasi dua arah yang ekstensif, (5) Menciptakan rasa komunitas seperti membangun homogenitas berdasarkan nilai; keadilan; menekankan kerja sama, saling mendukung, dan kerja tim, berkumpul bersama, (6) Mendukung perkembangan masyarakat yaitu melakukan aktualisasi; memberikan pekerjaan menantang pada tahun pertama; memajukan dan memberdayakan; mempromosikan dari dalam; menyediakan aktivitas perkembangan; menyediakan keamanan kepada masyarakat tanpa jaminan.

Komitmen dalam melaksanakan tugas seperti di atas ditandai dengan kesediaan dosen untuk terlibat dalam berbagai kegiatan kampus termasuk kegiatan berinovasi, bekerja dan berupaya untuk kemajuan kampus, memberikan tenaga, pikiran, ide, waktu agar program kampus berkembang dan mencapai kemajuan, memberikan informasi-informasi positif, menonjolkan kelebihan-kelebihan yang dimiliki dan merasa bangga menjadi dosen serta memiliki pemikiran untuk tetap menjadi dosen, merasa akan menemukan masalah dan hambatan jika keluar dari keanggota dosen. Menurut Juwono (2008: 50), komitmen dalam melaksanakan tugas memiliki tiga komponen yaitu sikap, afeksi dan kehendak untuk bertingkah laku. Sikap mencakup (1) Identifikasi diri yaitu penerimaan tujuan kelompok, dimana penerimaan ini merupakan dasar komitmen dalam melaksanakan tugas. Identifikasi diri dosen tampak melalui sikap menyetujui kebijaksanaan kelompok, kesamaan nilai pribadi dan nilai-nilai kelompok, rasa kebanggaan menjadi bagian dari kelompok.

(2) Keterlibatan sesuai peran dan tanggungjawab pekerjaan di kelompok tersebut. Masyarakat yang memiliki komitmen tinggi akan menerima hampir semua tugas dan tanggungjawab pekerjaan yang diberikan padanya.

Dosen yang memiliki komitmen tinggi akan memiliki identifikasi terhadap kelompok, terlibat sungguh-sungguh dalam pelaksanaan tugas dan ada loyalitas serta afeksi positif terhadap kelompok. Komitmen dosen adalah 
suatu janji pada diri sendiri ataupun orang lain yang tercermin dalam tindakan dalam melaksanakan tugas. Menurut Bernadib (2002: 116) bahwa komitmen berinovasi adalah penerimaan yang kuat dari individu terhadap tujuan dan nilai-nilai dimana ia bekerja dan individu tersebut akan berusaha dan berkarya serta memiliki hasrat yang kuat untuk tetap bertahan.

\section{Hubungan Komitmen Berinovasi dan Budaya Mutu Dosen}

Karakteristik organisasi yang memiliki budaya mutu adalah karyawan terlibat dan diberdayakan, pekerjaan masuk dalam sebuah tim, manajer tingkat eksekutif diikutsertakan dan dilibatkan; tanggung jawab kualitas tidak didelegasikan, sumber daya yang memadai disediakan di mana pun dan kapan pun dibutuhkan untuk menjamin perbaikan mutu secara berkesinambungan. Selain itu ciri organisasi yang memiliki budaya mutu adalah senantiasa melakukan pendidikan dan pelatihan diadakan agar para karyawan pada semua tingkat memiliki pengetahuan dan keterampilan yang dibutuhkan untuk meningkatkan mutu secara berkesinambungan. Disamping itu karakteristik lain organisasi yang memiliki budaya mutu, yaitu: (1) Komunikasi yang terbuka dan kontinyu, (2) Kemitraan internal yang saling mendukung, (3) Pendekatan kerjasama tim dalam suatu proses dan dalam mengatasi masalah, (4) Obsesi terhadap perbaikan terus menerus, (5) Pelibatan dan pemberdayaan karyawan secara luas, (6) Menginginkan masukan dan umpan balik/feed back dari pelanggan. Untuk memenuhi tuntutan tersebut maka sangat dibutuhkan komitmen berinovasi dari dosen. Dosen yang memiliki komitmen berinovasi akan mempunyai nilai, keyakinan dan perilaku sesuai dengan tuntutan mutu yang ditetapkan perguruan tinggi. Komitmen berinovasi yang kuat diperlukan untuk meningkatkan budaya mutu sehingga pada akhirnya akan berpengaruh pada kinerja dosen. Setiap dosen yang memiliki komitmen berinovasi akan berdampak pada perilaku dan sikap setiap dosen dalam melaksanakan tridharma perguruan tinggi seperti melakukan penelitian dan pengembangan, melakukan pengabdian kepada masyarakat.
Komitmen berinovasi dosen merupakan pola asumsi-asumsi yang mendasar dimana kelompok yang ada mengembangkan menciptakan, menemukan atau berkembang dalam proses belajar untuk menanggulangi kesulitan-kesulitan adaptasi eksternal dan integrasi internal. Komitmen berinovasi adalah perekat sosial yang mengingat anggota dari organisasi sehingga melahirkan pola kepercayaan, nilai-nilai, dan cara yang dipelajari menghadapi pengalaman yang telah dikembangkan sepanjang sejarah organisasi yang memanifestasi dalam pengaturan material dan perilaku anggota. Semakin banyak dosen yang memiliki komitmen berinovasi, semakin kuat upaya perguruan tinggi meningkatkan budaya mutu dosen. Berdasarkan hasil kajian teoretis maka hipotesis penelitian ini dirumuskan bahwa komitmen berinovasi berpengaruh langsung positif terhadap budaya mutu dosen di Universitas Muhammadiyah Luwuk.

\section{METODE PENELITIAN}

Metode yang digunakan dalam penelitian ini adalah survey kausal dengan model analisis jalur yang digunakan untuk menguji pengaruh langsung komitmen berinovasi terhadap budaya mutu dosen di Univeritas Muhammadiyah Luwuk. Penelitian ini terdapat dua yaitu komitmen berinovasi sebagai variabel bebas (X) dan budaya mutu sebagai variabel tak bebas (Y). Populasi penelitian adalah keseluruhan subyek yang berkaitan dengan budaya mutu dan komitmen berinovasi dosen pada Universitas Muhammadiyah Luwuk berjumlah 111 orang yang tersebar pada 8 Fakultas. Sampelnya diambil secara proporsional yang secara cara random sampling dengan memberi kesempatan yang sama pada anggota populasi untuk dipilih menjadi sampel penelitian (Sugiyono, 2004: 134).

\section{Definisi Operasional}

Budaya mutu adalah presepsi dosen terhadap aktifitas akademik yang dilakukan dalam melaksanakan tugas diperguruan tinggi. Kisi-kisi Intrumen Budaya Mutu Dosen, meliputi: Perilaku mengacu pada tuntunan agama dan norma-norma umum; Perilaku yang dibangun untuk berprestasi; Perilaku dalam memberikan keteladanan dan jiwa sosial bagi peserta didik; Standar perilaku; Cara bertindak; kaidah yang dominan prinsip; 
mekanisme penetapan kebijakan utama yang diyakini dalam mengaplikasikan TQM; Mekanisme penetapan kebijakan; Kebijakan yang bersifat krusial; Penerapan aturan; Tujuan penerapan aturan yang berlaku; Komunikasi pimpinan dengan bawahan; dan Pemberian pengakuan bagi yang berprestasi.

Komitmen berinovasi adalah persepsi dosen terhadap pengembangan proses akademik yang dilakukaan oleh dosen menyangkut kepatuhan terhadap inovasi dalam kegiatan akdemik. Kisi-Kisi Instrumen Komitmen berinovasi, meliputi: emosional, identifikasi, keterlibatan dalam berinovasi, kesetiaan, kewajiban yang harus diberikan kepada organisasi, kerugian bila meninggalkan organisasi, dan karyawan membutuhkan organisasi.

\section{Teknik Analisis Data}

Analisis terhadap data hasil pengukuran variabel penelitian yang diperoleh melalui kegiatan penelitian ini adalah analisis deskriptif dan inferensial. Menurut Sugiyono (2009:169), analisis deskriptif dimaksudkan untuk memberikan gambaran karakteristik penyebaran skor dengan melakukan perhitungan terhadap harga rata-rata, simpangan baku dan penghitungan persentasi distribusi frekuensi dari skor hasil pengisian angket. Analisis statistik inferensial digunakan untuk menguji hipotesis penelitian bahwa komitmen berinovasi berpengaruh langsung positif terhadap budaya mutu dosen di Universitas Muhammadiyah Luwuk.

\section{HASIL PENELITIAN DAN PEMBAHASAN Hasil Penelitian}

Hasil olahan data variabel budaya mutu dosen mempunyai nilai rata-rata sebesar 115 dan simpangan baku sebesar 11,84. Secara distribusi frekuensi, bahwa terdapat 24 orang atau 39\% responden memperoleh skor dibawah kelas interval rata-rata, sebanyak 12 orang atau $18 \%$ yang memiliki skor berada pada kelas interval rata-rata dan sebanyak 31 orang atau $43 \%$ yang memperolah skor di atas kelas interval rata-rata. Memperhatikan hasil pengolahan data tersebut maka kecenderungan responden memiliki skor diatas kelas interval rata-rata yaitu sejumlah 31 orang atau $43 \%$ responden. Berdasarkan pengukuran melalui angket dapat disimpulkan bahwa budaya mutu dosen memiliki skor dominan di atas kelas interval rata-rata.

Hasil olahan data variabel komitmen berinovasi mempunyai nilai rata-rata sebesar 101,76 dan simpangan baku sebesar 11,60. Secara distribusi frekuensi terdapat 30 orang atau $45 \%$ responden memperoleh skor dibawah rata-rata, 15 orang atau $22 \%$ responden yang memiliki skor pada kelas interval rata-rata dan sebanyak 22 orang atau $33 \%$ responden yang memperoleh skor di atas rata-rata.

Memperhatikan hasil ini menunjukkan kecenderungan responden memiliki skor di bawah rata-rata sebanyak 30 orang atau $45 \%$, menunjukkan kecenderungan komitmen berinovasi dibawah skor kelas interval ratarata. Sebaliknya, terdapat 37 orang atau 55\% memiliki skor di atas interval rata-rata, menggambarkan kecenderungan komitmen berinovasi responden di atas skor kelas interval rata-rata. Pengujian hipotesis menggunakan teknik analisis statistik parametrik uji $\mathrm{F}$ yang dihitung menggunakan software SPSS. Hasil analisis diperoleh persamaan regresi $\hat{Y}=50,06+0,65 X$, koefisien korelasi $\left(\mathrm{r}_{\mathrm{xy}}\right)=0,629$ dan $\mathrm{F}_{\text {hit }}=$ 42,593, dengan $\mathrm{p}$-value $=0,000<0,05$, menunjukkan Ho ditolak. Hasil uji menggambarkan bahwa model regresi $\mathrm{Y}$ atas $\mathrm{X}$ adalah signifikan.

Merujuk pada hasil perhitungan regresi sederhana pengaruh komitmen berinovasi terhadap budaya mutu model regresi $\mathrm{Y}$ atas $\mathrm{X}$ yaitu $\hat{\mathrm{Y}}=50,06+0,65 \mathrm{X}$ diperoleh nilai $\mathrm{F}_{\text {hitung }}(\mathrm{TC})=0,687$ dengan $\mathrm{p}$ value $=0,856>0,05$. Hal ini berarti Ho diterima, menggambarkan bahwa persamaan regresi $\hat{\mathrm{Y}}=50,06+0,65 \mathrm{X}$ adalah linier. Artinya, persamaan regresi variabel budaya mutu atas komitmen berinovasi bersifat sangat linear.

Hasil uji pengaruh langsung positif komitmen berinovasi terhadap budaya mutu, diperoleh koefisien jalur komitmen berinovasi (X) terhadap budaya mutu $(\mathrm{Y})$, yakni $\mathrm{p}_{\mathrm{y} 1}=$ 0,232 dengan $\mathrm{t}_{\text {hitung }}=2,35$ dan $\mathrm{t}_{\text {tabel }(\alpha=0,05 ; \mathrm{dk}=63)}=$ 1,99. Hasil ini menunjukkan $t_{\text {hitung }}>t_{\text {tabel, }}$ atau p-value $=0,022 / 2=0,011<0.05$ yang berarti $\mathrm{H}_{\mathrm{o}}$ ditolak atau koefisien jalur antara komitmen berinovasi dan budaya mutu signifikan. Hal ini berarti bahwa terdapat pengaruh langsung positif komitmen berinovasi terhadap budaya mutu. 


\section{Pembahasan Penelitian}

Berdasarkan persamaan koefisien jalur komitmen berinovasi (X) ke budaya mutu $(\mathrm{Y})$ yakni $\mathrm{p}_{\mathrm{y} 1}=0,232$ dengan $\mathrm{t}_{\text {hitung }}=2,35$ dan $\mathrm{t}_{\text {tabel }(\alpha=0,05 ; \mathrm{dk}=63)}=1,99$. Dengan demikian $\mathrm{t}_{\text {hitung }}>\mathrm{t}_{\text {tabel, }}$ atau $\mathrm{p}$-value $=0,022 / 2=0,011<$ 0.05 yang berarti $\mathrm{H}_{\mathrm{o}}$ ditolak atau koefisien jalur antara komitmen berinovasi dan budaya mutu signifikan. Hal ini berarti bahwa terdapat pengaruh langsung positif komitmen berinovasi terhadap budaya mutu. Hal ini menunjukkan bahwa komitmen berinovasi memberikan konstribusi terhadap peningkatan budaya mutu.

Komitmen berinovasi menjadi faktor yang mempengaruhi budaya mutu dosen karena dengan terciptanya komitmen berinovasi yang baik setiap individu akan mengikatkan dirinya dalam nilai-nilai, aturanaturan, kebijakan prosedur dalam setiap tingkah lakunya untuk menjalankannya sebagai bagian dari organisasi. Komitmen berinovasi umumnya mempengaruhi perilaku anggota organisasi sehingga dapat menciptakan suatu kondisi yang mendorong anggota organisasi untuk bekerja dengan baik dan berkeinginan meraih sukses. Seseorang yang menunjukkan budaya mutu akan ditunjukkan oleh citra diri yang positif yang terbangun dalam komitmen berinovasi yang baik. Karena itu tidak berlebihan jika komitmen berinovasi berpengaruh langsung terhadap kepuasan kerja dan juga memiliki berpengaruh langsung maupun tidak langsung terhadap budaya mutu. Hal ini sesuai dengan pendapat Siagian (2002:189) bahwa nilai-nilai sosial budaya menentukan yang baik, tidak baik, benar, salah, wajar, tidak wajar dan sebagainya. Nilai-nilai tersebut digunakan untuk menilai perilaku seseorang, baik sebagai individu maupun sebagai anggota kelompok, termasuk kelompok kerja di mana seseorang berkarya.

Komitmen afektif dalam berinovasi merupakan keterikatan emosional seseorang dosen pada kegiatan yang bersifat inovasi, sehingga sangat bermanfaat bagi pengembangan dalam organisasi. Komitmen berkelanjutan dalam berinovasi dapat dinyatakan sebagai fenomena yang terstruktur sebagai hasil dari transaksi pegawai dengan organisasi dan investasi yang diberikan pada organisasi. Komitmen normatif dalam berinovasi merupakan perasaan-perasaan dosen tentang kewajiban yang diberikan kepada organisasi. Sesuatu yang mendorong dosen untuk tetap berada dan memberikan sumbangan terhadap keberadaan pengembangan kampus kedepan, baik materi maupun non materi, merupakan kewajiban moral, yang mana seseorang akan merasa tidak nyaman dan bersalah jika tidak melakukan suatu inovasi.

Uraian diatas sesuai hasil penelitian Sudiatmi (2012) bahwa komitmen pada profesi berpengaruh signifikan terhadap motivasi untuk berprestasi. Seorang dosen saat ini dituntut untuk memiliki sikap profesional dalam menjalankan Tri Dharma PT dengan selalu melaporkan kegiatannya secara periodik. Kecintaan dan kebanggaan terhadap profesi merupakan indikator sikap profesional dosen. Dosen yang memiliki komitmen berinovasi berdampak pada meningkatnya nilai-nilai yang dapat menciptakan budaya mutu. Komitmen adalah janji yang bentuknya berupa kepedulian seseorang terhadap profesinya. Berdasarkan uraian diatas, dapat disimpulakan bahwa terdapat pengaruh yang signifikan positif komitmen berinovasi terhadap budaya mutu dosen di Universitas Muhammadiyah Luwuk.

\section{E. PENUTUP \\ Kesimpulan}

Berdasarkan hasil penelitian dan pembahasan maka kesimpulan penelitian ini adalah terdapat pengaruh langsung positif komitmen berinovasi terhadap budaya mutu dosen. Pengaruh ini menunjukkan bahwa peningkatan komitmen berinovasi secara langsung akan meningkatkan budaya mutu dosen. Berdasarkan temuan penelitian ini, maka budaya mutu dosen dapat ditingkatkan dengan menanamkan komitmen berinovasi yang baik dalam sistem manejemen organisasi perguruan tinggi, khususnya di Universitas Muhamadiyah Luwuk.

\section{Implikasi}

Hasil penelitian ini memberikan implikasi, apabila komitmen berinovasi yang dimiliki dosen ditingkatkan, maka akan semakin tinggi budaya mutu. Upaya ini dapat dilakukan melalui kegiatan: memperbaiki hubungan internal organisasi sehingga terbangun kerja sama yang efektif antar anggota organisasi, membangun sistem nilai 
dan norma yang akan mempengaruhi cara kerja dan perilaku seseorang sesuai dengan tujuan organisasi, membina integritas dan sikap terbuka antar sesama dosen, dan membangun komitmen dosen untuk mematuhi norma dan aturan yang berlaku di Universitas Muhammadiyah Luwuk.

\section{Saran-Saran}

Berdasarkan temuan penelitian, kesimpulan dan implikasi penelitian maka dapat diajukan beberapa saran terhadap pihakpihak berikut :

1. Bagi dosen disarankan senantiasa membangun dan menjaga sistem nilai dalam komitmen berinovasi untuk menigkatkan budaya mutu dalam rangka meningkatkan mutu pendidikan di Universitas Muhammadiyah Luwuk pada khusunya dan umumnya Pendidikan Tinggi di Indonesia dan menjadikan penelitian ini dapat menambah pengetahuan sebagai bekal dalam menerapkan ilmu guna menunjang pelaksanaan tugas, memperoleh pengalaman awal berpikir teoritis.

2. Bagi Universitas Muhammadiyah Luwuk senantiasa menggunakan hasil penelitian ini untuk dapat memacu selangkah lebih maju, dan mampu berkompetisi teruatama dalam pengelolaan dan pemberdayaan SDM yang ada di Universitas Muhammadiyah Luwuk dan pada gilirannya akan dapat menghasilankan luaran yang berkualitas.

3. Bagi Majelis Diktilitbang Pimpinan Pusat Muhammadiyah. agar lebih intensif dalam melakukan pembinaan terhadap keberlangsungan perguruan tinggi Muhammadiyah. Khususnya Universitas Muhammadiyah Luwuk dalam upaya memberikan pembinaan terhadap Sumber Daya manusianya, baik dosen maupun tenaga kependidikan lainnya.

4. Bagi Peneliti diharapkan dapat melanjutkan penelitian yang lebih mendalam pada variabel yang berpengaruh negatif yakni lingkungan eksternal, khususnya dimensi kebijakan pemerintah, partisipasi masyarakat, Sampel penelitian tidak dibatasi hanya pada dosen, tetapi juga pada seluruh civitas akademika.

\section{DAFTAR PUSTAKA}

Davis, A., 2004. Managing Corporate Culture. Cambridge, MA: Belinger.

Gibson, James L., John M. Ivancevich dan James H. Donnelly, Jr. 2006. Organisasi, Perilaku, Struktur, Proses. Alih Bahasa Nunuk Adiarni, Penerbit Binarupa Aksara, Jakarta.

Griffin, Jill. 2008. Costumer Loyalty How to Earn it, How to Keep it. Lexington Books: Singapore.

Luthans, Fred. 2008. Organization Behavior. International Edition, Sixth Edition, Mc Graw-Hill, Singapore.

Robbin, Stephen, P. 2001. Prinsip-Prinsip Prilaku Organisasi, Edisi Ke Lima, Jakarta Erlangga.

Siagian, Sondang, 2002. Manajemen Sumber Daya Manusia. Jakarta : PT. Bumi Askara.

Stoner, James A. F. dan Edward Freeman, Daniel R. Gilbert, Jr. 2006. Manajemen. Edisi Indonesia, Alih Bahasa Alexander Sindoro, PT. Prehallindo, Jakarta.

Sudiatmi Titi. 2012. Pengaruh Komitmen Pada Profesi Dan Dukungan Organisasional Terhadap Motivasi Berprestasi Dosen pada Program Studi Pendidikan Bahasa danSastra Indonesia Fakultas Keguruan dan Ilmu Pendidikan Universitas Veteran Bangun Nusantara Sukoharjo. Sukoharjo. Universitas Veteran Bangun Nusantara Sukoharjo.

Sugiyono. 2004. Metode Penelitian Administrasi. Bandung : CV Alfabeta. 2009. Statistika untuk Penelitian. Bandung : CV Alfabeta

Yuwono, I dkk. 2005. Psikologi Industri dan Organisasi".Surabaya: Fakultas Psikologi Universitas Airlangga. 